\title{
Removal of Organic Matter from Paper Mill Effluent by Electrochemical Oxidation
}

\author{
Teresa Zayas $^{1,2}$, Mario Picazo ${ }^{1}$, Leonardo Salgado ${ }^{3}$ \\ ${ }^{1}$ Posgrado en Ciencias Ambientales y \\ ${ }^{2}$ Centro de Química del Instituto de Ciencias, \\ Benemérita Universidad Autónoma de Puebla, Puebla, México \\ ${ }^{3}$ Depto. de Química, Universidad Autónoma Metropolitana Iztapalapa, \\ México D.F., MEXICO \\ E-mail: tzayasp@hotmail.com
}

Received October 25, 2010; revised November 29, 2010; accepted December 31, 2010

\begin{abstract}
The electrochemical oxidation of paper mill wastewater was studied using a dimensionally stable anode of composition $\mathrm{Ti} / \mathrm{RuPb}(40 \%) \mathrm{Ox}$. The oxidation process was analyzed as a function of electrolysis time and with respect to the cell potential difference, electrolyte $(\mathrm{NaCl})$ concentration, and $\mathrm{pH}$ of the sample. The purification of the effluent was evaluated through measurements of the removal of chemical oxygen demand (COD), color, and total polyphenols, and using UV-Vis spectroscopy. The results showed that the presence of $\mathrm{NaCl}$ is a determining factor in the purification process. Electrolysis of wastewater containing $5 \mathrm{~g} / \mathrm{L} \mathrm{NaCl}$ at a cell potential difference of $6 \mathrm{~V}$ for $120 \mathrm{~min}$, removed 99\% of COD and the percent removal values of color and polyphenols were $95 \%$ after 15 min of electrolysis. The UV-Vis spectrum showed evidence of the formation of hypochlorite ions $\left(\mathrm{ClO}^{-}\right)$during the electrolysis process, indicating that the electrochemical oxidation proceeds via an indirect mechanism with the participation of hypochlorite ions.
\end{abstract}

Keywords: Paper Mill Wastewater, Electrochemical Oxidation, Ti/RuPb(40\%)Ox Anode

\section{Introduction}

The wastewater produced by pulp and paper mills is a serious environmental hazard because it contains diverse chemical compounds and is produced in large volumes. More than 250 chemicals have been identified in effluents produced at different stages of papermaking [1]. The high organic content of these effluents is primarily in the form of chlorinated compounds, suspended solids (mainly fibers), fatty acids, tannins, resin acids, lignin and its derivatives, and sulfur compounds. Given that chlorinated organic compounds such as dioxins and furans can induce genetic changes in exposed organisms [2], there is a pressing need for effective methods for purifying paper mill wastewater prior to discharge into bodies of water.

The classical treatment applied to pulp and paper mill effluent consists of an initial clarification step followed by a secondary biological treatment (anaerobic or aerobic and activated sludge) $[3,4]$. Although such treatments have been used to reduce the organic content, they fail to remove diverse recalcitrant organic compounds that resist the biological degradation and hence remain in the effluent. In an effort to develop more effective methods for purifying the effluent produced by the pulp and paper industry, various studies have examined treatments based on biological processes (aerobic, anaerobic, algal, fungal biomass) [5-7] and physicochemical approaches (coagulation-flocculation, ozonation, photocatalysis, electrochemistry) [8-12].

Electrochemical methods for wastewater treatment have attracted increasing interest due to their outstanding capacity to eliminate a wide variety of pollutants normally present in wastewaters, such as refractory organic matter [13]. Electrocoagulation and electrochemical oxidation have been applied to the study of purification of wastewater from paper mill. Buzzini et al. [14] conducted an exploratory study to test the technical feasibility of electrolytic treatment and coagulation followed by flocculation and sedimentation as post-treatment of effluent from a UASB reactor treating simulated wastewater from an unbleached Kraft pulp mill. They found that 
electrolytic treatment removed up to $67 \%$ of the remaining COD and $98 \%$ of the color from the wastewater. In a study on paper mill wastewater treatment, Ugurlu et al. [15] investigated the removal of COD, lignin, and phenol using an electrochemical cell consisting of a graphite electrode and powder-activated carbon as the working electrode. They found that more than $90 \%$ of COD, lignin and phenol was removed by electrolysis under the following conditions: cell voltage, $25.0 \mathrm{~V} ; 5.0 \mathrm{~min}$, in presence of air $2.0 \mathrm{Lmin}^{-1} ; 5.0 \mathrm{~g} \mathrm{~L}^{-1} \mathrm{NaCl}$; low $\mathrm{pH}$; and $20 \mathrm{~g} \mathrm{~L}^{-1}$ activated carbon. Mahesh et al. [12] investigated the electrochemical degradation of agri-based paper mill wastewater (black liquor) in a $2 \mathrm{dm}^{3}$ electrolytic batch reactor using iron plate electrodes. Under optimal conditions (current density $55.56 \mathrm{~A} / \mathrm{m}^{2}$ at neutral $\mathrm{pH}$ with a six-plate arrangement), $80 \%$ and $90 \%$ of COD and color were removed, respectively. The authors found that treatment time could be significantly reduced, and the sludge settling characteristics improved, by increasing the salinity. In a recent study of electrocoagulation treatment of black liquor from the paper industry, Zaied and Bellakhal [16] found that, under the optimal experimental conditions (initial $\mathrm{pH} \mathrm{7,} \mathrm{electrolysis} \mathrm{time}=50$ min and $J=14 \mathrm{mAcm}^{-2}$ ), such treatment of black liquor removed $98 \%$ of COD and $92 \%$ of polyphenols and reduced the color intensity by $99 \%$. In the same year (2009), Khansorthong and Hunsom [17], reported the optimum conditions for color and total COD reduction in wastewater from the pulp and paper mill industry by using electrocoagulation techniques. The results indicated that at optimum conditions, greater than $97 \%$ of color and $77 \%$ of total COD were effectively removed.

The removal of organic contaminants by electrochemical oxidation at titanium electrodes coated with noble oxides has been shown to be an effective means of wastewater treatment because of its performance, stability, cost, and lifetime [18-20]. However, only limited information is available about the application of these electrodes on the electrochemical oxidation of organic matter from paper mill wastewater.

We therefore investigated the performance of $\mathrm{Ti} / \mathrm{RuPb}$ $(40 \%) \mathrm{O}_{\mathrm{X}}$ as type dimensionally stable anode in the process of oxidation electrochemistry of paper mill wastewater. The effects of the potential difference, electrolyte $(\mathrm{NaCl})$ concentration, and $\mathrm{pH}$ of the solution on the removal of COD, color and total polyphenols were analyzed.

\section{Materials and Methods}

\subsection{Characteristics of the Paper Mill Effluent}

The wastewater samples used in this study were obtained from a paper production plant, and stored at $4^{\circ} \mathrm{C}$. The characteristics of the raw effluent are listed in Table 1.

\subsection{Materials}

Experiments were conducted in cylindrical Pyrex cells of $150 \mathrm{~cm}^{3}$ capacity. A $\mathrm{Ti} / \mathrm{RuPb}(40 \%) \mathrm{Ox}$ electrode was used as the anode and a $\mathrm{Ti} / \mathrm{PtPd}(10 \%) \mathrm{Ox}$ electrode was employed as the cathode. The mesh area of the electrodes was $41.25 \mathrm{~cm}^{2}(7.5 \mathrm{~cm} \times 5.5 \mathrm{~cm})$. The electrodes were prepared in our laboratory following the method described in reference [22]. Sodium chloride (Merck AR) was used as the support electrolyte. Sodium hydroxide and hydrochloric acid solutions were prepared at $1 \mathrm{M}$ concentrations in deionized water using sodium hydroxide (Merck AR) and hydrochloric acid (37\% by mass, Merck, AR). These solutions were used to adjust the $\mathrm{pH}$ of the raw wastewater samples. $\mathrm{pH}$ measurements were performed using a Conductronic PC $18 \mathrm{pH}$ meter. COD, color and turbidity were monitored using a spectrophotometer (SQ118, Merck) at wavelengths: 585, 446 and $525 \mathrm{~nm}$, respectively. The COD expresses the amount of oxygen originating from potassium dichromate that reacts with the oxidizable substances in the samples and was evaluated using COD vials (Merck, Germany) with different sensitivity ranges. Sample digestion was performed in a TR 300 Thermoreaktor (Merck) over 2 hours at $148^{\circ} \mathrm{C}$. UV-Vis spectra of the samples were obtained using a Perkin-Elmer Lambda 20 spectrometer. The total polyphenol content was determined colorimetrically using the Folin-Ciocalteu reaction [21]. Chloride determination was carried out using the Spectroquant chloride test (Merck Germany).

\subsection{Electrochemical Methodology}

The electrochemical oxidation process was performed in an electrochemical cell with a sample volume of $100 \mathrm{~mL}$. The parallel electrodes were placed vertically with a separation distance of $3 \mathrm{~mm}$. Raw wastewater samples were subjected to electrolysis with and without a support

Table 1. Characteristic parameters of the raw paper mill wastewater.

\begin{tabular}{lc}
\hline Parameters & Values \\
\hline $\mathrm{COD}\left(\mathrm{mg} \mathrm{O}_{2} / \mathrm{L}\right)$ & 2585 \\
Conductivity $\left(\mathrm{mS} \mathrm{cm}^{-1}\right)$ & 2.9 \\
Color $\left(\mathrm{m}^{-1}\right)$ & 101.2 \\
Turbidity $(\mathrm{NTU})$ & 486 \\
$\mathrm{pH}$ & 6.3 \\
$\mathrm{TDS}(\mathrm{g} / \mathrm{L})$ & 2.1 \\
Chloride concentration $(\mathrm{mg} / \mathrm{L})$ & 80 \\
Total polyphenols $(\mathrm{mg} / \mathrm{L})$ & 48 \\
\hline
\end{tabular}


electrolyte. The operation variables were the cell potential difference, electrolysis time, concentration of support electrolyte $(\mathrm{NaCl})$, and $\mathrm{pH}$ of the solution. The potential difference was applied from an external power source (DS-304M, Zurich), and current and voltage were measured using a multimeter (MUL-500, Steren). The effects of the electrochemical treatment were analyzed by determining physicochemical parameters such as COD, color, polyphenol content, and chloride concentration, as well as examining UV-vis spectra. The experimental design was based in obtaining high efficiency in the removal of organic matter with low cell potential differences and optimal conditions of $\mathrm{pH}$ and electrolyte $(\mathrm{NaCl})$ concentration.

\section{Results and Discussion}

\subsection{Effect of Potential Difference}

Raw wastewater samples without the support electrolyte $(\mathrm{NaCl})$ were subjected to electrolysis with various cell potentials and examined as a function of electrolysis time. The effect of the potential difference was analyzed in terms of the variations of COD, color, polyphenols, and final $\mathrm{pH}$.

The variations in COD removal as a function of electrolysis time at cell potentials of 4, 6 and $8 \mathrm{~V}$ are shown in Figure 1. For each applied potential difference, the percent COD removal increases with increasing electrolysis time and plateaus to a constant value that depends on the applied potential difference. For applied potentials of 4, 6 and $8 \mathrm{~V}$, the maximum values of the percent COD removal after $60 \mathrm{~min}$ of electrolysis were $38 \%, 55 \%$ and $61 \%$, respectively. Thus, after 60 min of electrolysis at the maximum applied potential difference of $8 \mathrm{~V}$, the removal of organic matter does not exceed $61 \%$.

The effect of the applied potential difference on color

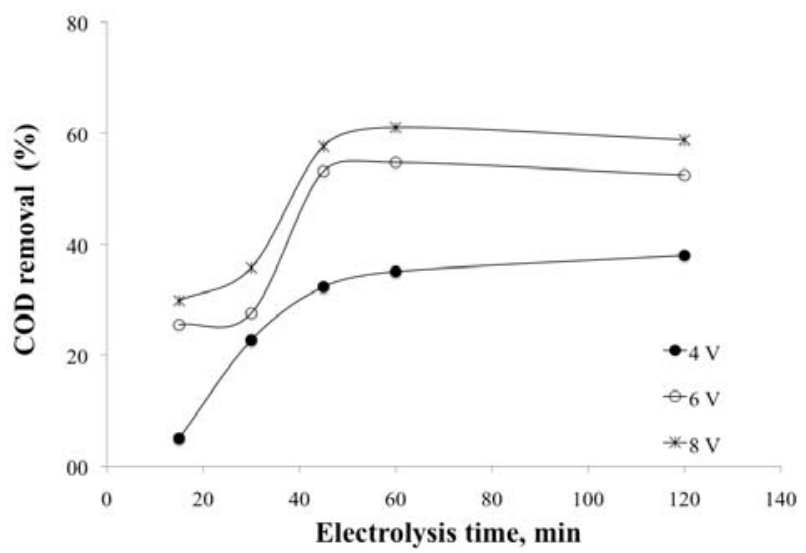

Figure 1. Percent COD removal as a function of electrolysis time at different cell potentials. removal can be seen in Figure 2. The removal of color increases with increasing potential difference and electrolysis time. The highest color removal values were obtained at $8 \mathrm{~V}$. In this case, the color removal reached $90 \%$ after $45 \mathrm{~min}$ of electrolysis and $100 \%$ after $120 \mathrm{~min}$. The observation that the maximum COD removal was $61 \%$ and the maximum color removal was $90 \%$ indicates that the organic compounds responsible for the color are more prone to removal compared to the recalcitrant compounds that resisted removal.

The effect of the potential difference on polyphenol removal is shown in Figure 3. For each potential difference applied, the percent polyphenol removal increases with electrolysis time, reaching an almost constant value after $60 \mathrm{~min}$ of electrolysis. For the potential difference of $4 \mathrm{~V}$, the maximum polyphenol reduction was approximately $60 \%$. For $6 \mathrm{~V}$, the percent removal reached $83 \%$, while for $8 \mathrm{~V}, 91 \%$ of polyphenols were removed. These findings suggest that polyphenol removal and color removal show similar behavior as the applied potential difference is varied.

Electrolysis of the wastewater samples caused the $\mathrm{pH}$ to increase monotonically from an initial value of 6.3 to a final value $\left(\mathrm{pH}_{\mathrm{f}}\right)$ between 7 and 8 , where $\mathrm{pH}_{\mathrm{f}}$ depended on the applied potential (Figure 4). A similar trend was observed for all of the applied cell potentials. These findings indicate that the electrolysis process caused a reduction in the concentration of protons, leading to a slightly alkaline $\mathrm{pH}$. As reported by Rajeshwar et al. [23], the electrochemical oxidation of contaminants is accompanied by side reactions involving the solvent, for example:

$$
\begin{aligned}
& 2 \mathrm{H}_{2} \mathrm{O} \rightarrow \mathrm{O}_{2}+4 \mathrm{H}^{+}+4 \bar{e} \\
& 2 \mathrm{H}_{2} \mathrm{O}+2 \bar{e} \rightarrow \mathrm{H}_{2}+2 \mathrm{OH}^{-}
\end{aligned}
$$

Such reactions may be responsible for the change in $\mathrm{pH}$ observed during oxidation.

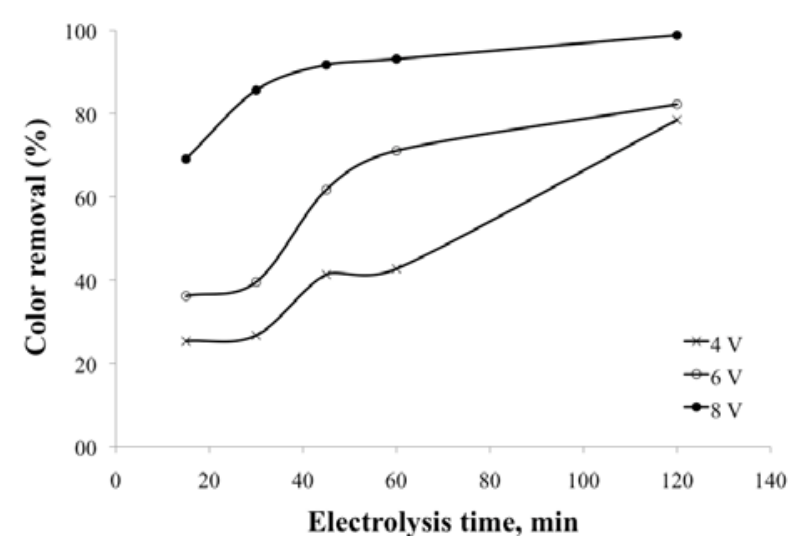

Figure 2. Percent color removal as a function of electrolysis time at different cell potentials. 


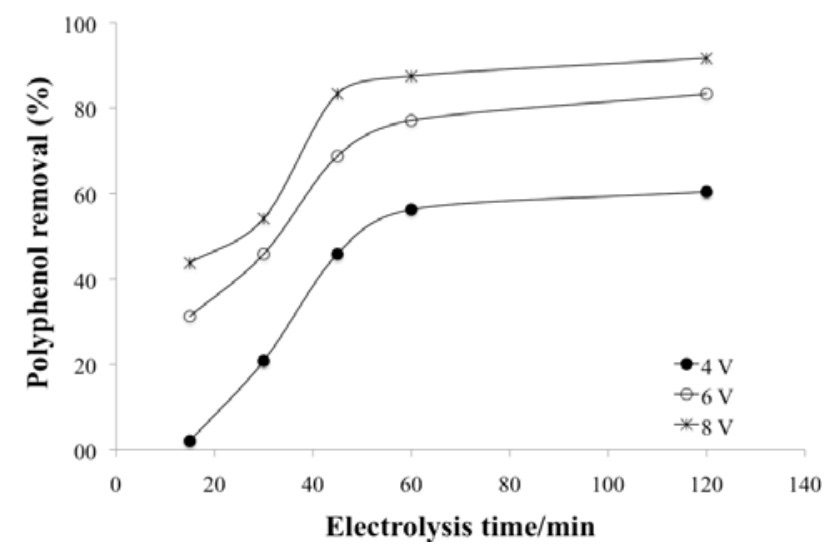

Figure 3. Percent polyphenol removal as a function of electrolysis time at different cell potentials.

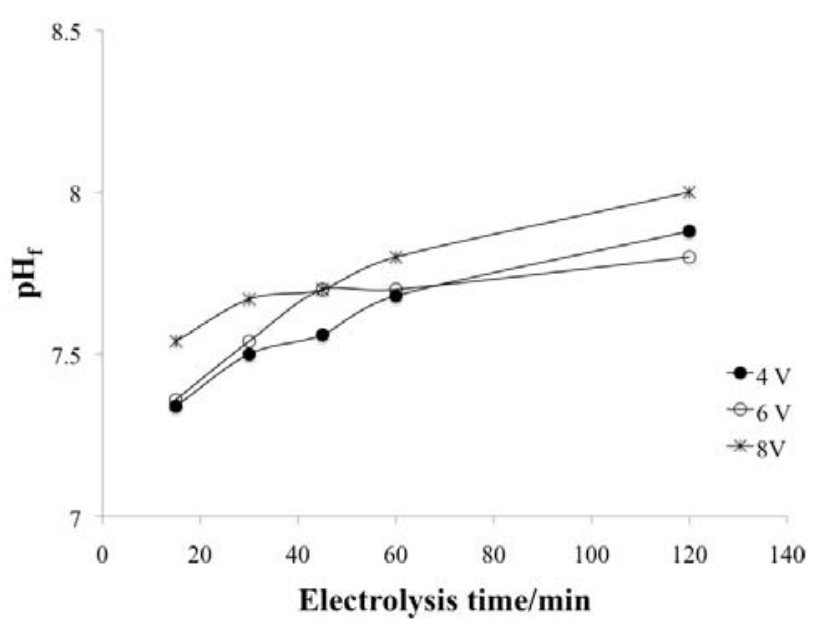

Figure 4. Variation of the final $\mathrm{pH}$ of wastewater samples as a function of electrolysis time at different cell potentials.

The behavior observed in our study of the variations in COD, color and polyphenols with increasing the cell potential difference and electrolysis time is consistent with previous findings $[15,24,25]$. For each potential difference applied, the percent removal of contaminants increases with electrolysis time and reaching a limiting value proportional to cell potential.

\subsection{Effect of Electrolyte Concentration}

Wastewater samples with different concentrations of $\mathrm{NaCl}$ as an electrolyte (1 to $5 \mathrm{~g} / \mathrm{L}$ ) and $\mathrm{pH} 6.3$ were subjected to electrolysis with a potential difference of $6 \mathrm{~V}$, and the removal of COD, color and polyphenols was examined as a function of electrolysis time for each system. The effect of support electrolyte concentration on COD removal is shown in Figure 5. The presence of $\mathrm{NaCl}$ promotes the removal of COD. For wastewater samples with $1 \mathrm{~g} / \mathrm{L}$ of $\mathrm{NaCl}, 53 \%$ of $\mathrm{COD}$ was removed

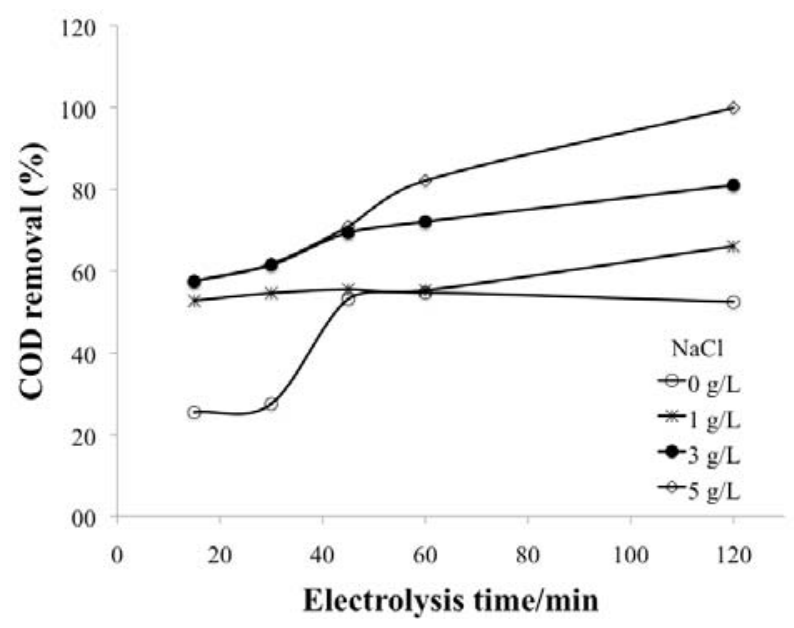

Figure 5. Percent COD removal as a function of electrolysis time at different concentrations of $\mathrm{NaCl}$. Cell potential difference, $6 \mathrm{~V}$.

after $15 \mathrm{~min}$ of electrolysis, whereas in the absence of $\mathrm{NaCl}$ a similar degree of removal was achieved only after $45 \mathrm{~min}$. The percent COD removal increased with increasing $\mathrm{NaCl}$ concentration and with electrolysis time. The maximum percent COD removal values, achieved after $120 \mathrm{~min}$ of electrolysis, were $66 \%, 81 \%$ and $99 \%$ for electrolyte solutions concentrations containing 1, 3 and $5 \mathrm{~g} / \mathrm{L} \mathrm{NaCl}$, respectively.

The effect of electrolyte concentration on the removal of color is shown in Figure 6. At each $\mathrm{NaCl}$ concentration, the percent color removal increases with increasing electrolysis time. As the electrolyte concentration increases, the curves of color removal as a function of electrolysis time converge to a maximum value close to $100 \%$. Thus, increasing the $\mathrm{NaCl}$ concentration serves to lower the electrolysis time required to reach a high percent color removal. For example, when the concentration of $\mathrm{NaCl}$ was $5 \mathrm{~g} / \mathrm{L}, 95 \%$ of color was removed after $15 \mathrm{~min}$ of electrolysis, whereas in the absence of $\mathrm{NaCl}$ only $36 \%$ of the color was removed after the same electrolysis time.

The curves of percent polyphenol removal as a function of electrolysis time (Figure 7) at various $\mathrm{NaCl}$ concentrations show behavior similar to that observed for color removal (Figure 6). Specifically, the polyphenol removal curves converge at a value close to $100 \%$ as electrolysis proceeds. At the highest $\mathrm{NaCl}$ concentration used $(5 \mathrm{~g} / \mathrm{L})$, almost $100 \%$ of polyphenols were removed within $15 \mathrm{~min}$. The trends observed in the removal of color and polyphenols as a function of electrolysis time and electrolyte concentration suggest that the polyphenols present in wastewater are responsible for the color of the samples.

Additionally in wastewater samples with a $\mathrm{NaCl}$ concentration $5 \mathrm{~g} / \mathrm{L}$, the increase in electrolysis time is 


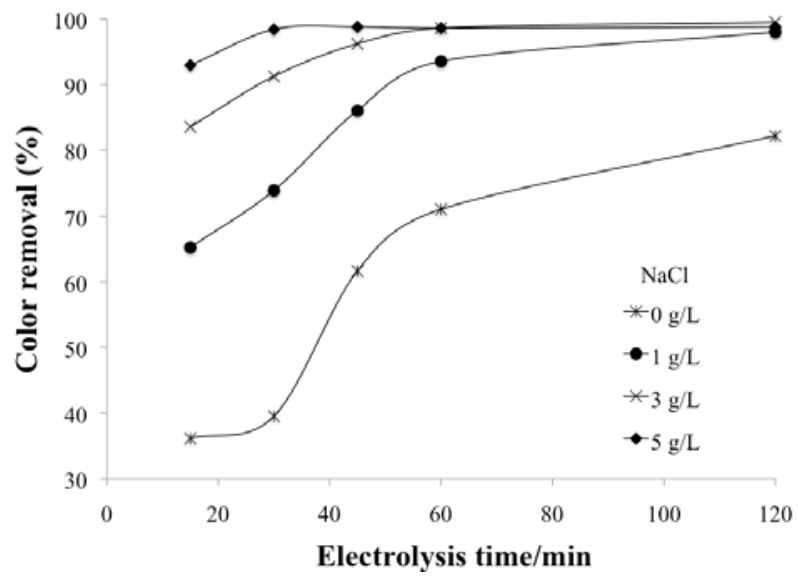

Figure 6. Percent color removal as a function of electrolysis time at different concentrations of $\mathrm{NaCl}$. Cell potential difference, $6 \mathrm{~V}$; initial $\mathrm{pH}, 6$.

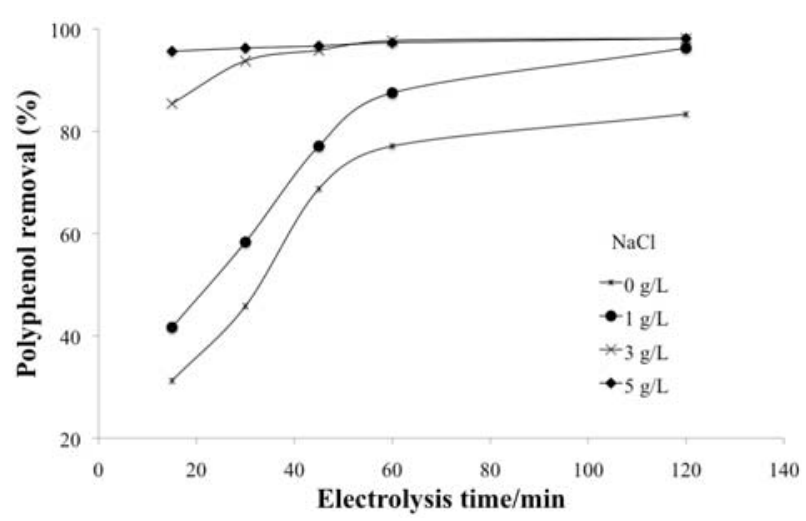

Figure 7. Percent polyphenol removal as a function of electrolysis time at different concentrations of NaCl. Cell potential difference, $6 \mathrm{~V}$; initial pH, 6.

accompanied by the emergence and growth of a peak in the UV-Vis spectrum (Figure 8(a)) at $\lambda=292 \mathrm{~nm}$, which is consistent with the presence of hypochlorite ions $\left(\mathrm{OCl}^{-}\right)$[26]. This result indicates that the electrolysis of paper mill wastewater with a $\mathrm{NaCl}$ concentration of $5 \mathrm{~g} / \mathrm{L}$ generates hypochlorite ions. However, when wastewater containing $\mathrm{NaCl}$ concentrations less than 2 $\mathrm{g} / \mathrm{L}$ was subjected to electrolysis, the absorbance peak at $292 \mathrm{~nm}$ was not observed (Figure 8(b)), indicating that the $\mathrm{OCl}^{-}$formed during electrolysis had been consumed in the oxidation of organic matter. In contrast, when an excess of electrolyte was used $(5 \mathrm{~g} / \mathrm{L} \mathrm{NaCl})$, the hypochlorite ions were produced in excess and could be detected in the UV-Vis spectrum (Figure 8(a)).

The results obtained show that the presence of $\mathrm{NaCl}$ in wastewater undergoing electrochemical oxidation facilitates the removal of COD, color and polyphenols. In addition, increasing the $\mathrm{NaCl}$ concentration gives more rapid removal of color and polyphenols, in agreement

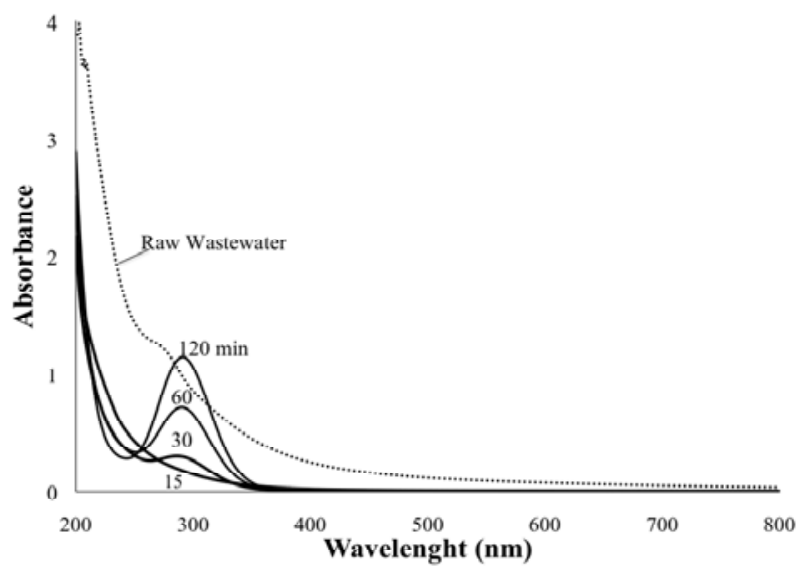

(a)

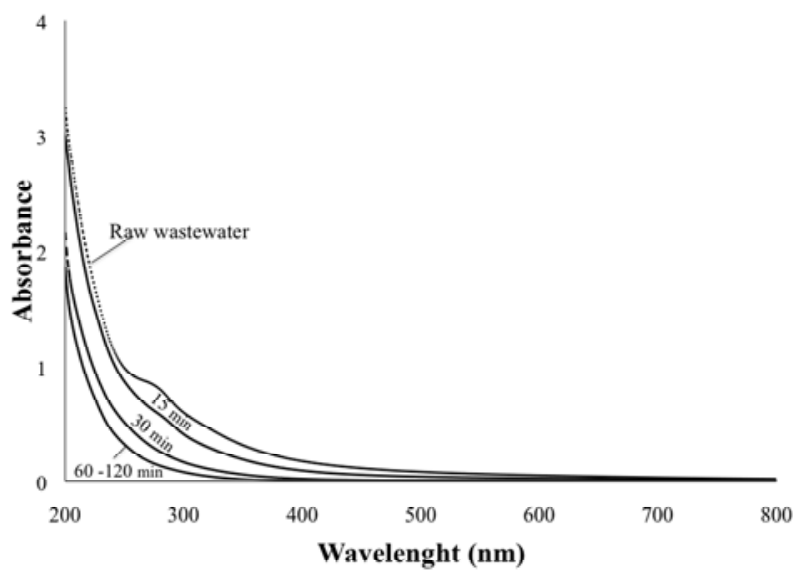

(b)

Figure 8. UV-Vis spectra of paper mill wastewater samples with $\mathrm{NaCl}$ concentrations of a) $5 \mathrm{~g} / \mathrm{L}$ and b) $1 \mathrm{~g} / \mathrm{L}$, after different electrolysis times. Cell potential difference, $6 \mathrm{~V}$.

with previously reported results $[27,28]$.

In general, organic pollutants can be destroyed electrochemically by either direct or indirect oxidation. In direct anodic oxidation, the pollutants are first adsorbed on the anode surface and then destroyed by the anodic electron transfer reaction. In indirect oxidation, by contrast, strong oxidants such as hypochlorite/chlorine, ozone, and hydrogen peroxide are electrochemically generated [23]. The electrochemical generation of hypochlorite/chlorine in a solution containing chloride ions proceeds according to the following reaction:

$$
\begin{aligned}
& 2 \mathrm{Cl}^{-} \rightarrow \mathrm{Cl}_{2}+2 \bar{e} \\
& \mathrm{Cl}_{2}+\mathrm{H}_{2} \mathrm{O} \rightarrow \mathrm{HOCl}+\mathrm{H}^{+}+\mathrm{Cl}^{-} \\
& \mathrm{HOCl} \rightarrow \mathrm{H}^{+}+\mathrm{OCl}^{-}
\end{aligned}
$$

The hypochlorite ion is powerful oxidizing agent that is referred to as active chlorine. Therefore, the pollutants are destroyed in the bulk solution by the oxidation reac- 
tion with the generated oxidant. Feng et al. [26] demonstrated that the active chlorine species in a solution depend fundamentally on the $\mathrm{pH}$. At $\mathrm{pH}<7$, $\mathrm{HClO}$ predominates, whereas hypochlorite ions predominate at $\mathrm{pH}$ $>7$. Thus, our results indicate that the electrooxidation of contaminants at the $\mathrm{Ti} / \mathrm{RuPb}(40 \%) \mathrm{Ox}$ anode proceeds via an indirect oxidation mechanism with the participation of hypochlorite ions.

\subsection{Effect of pH}

The effect of $\mathrm{pH}$ on the electrolysis process was analyzed in experiments using wastewater samples containing $5 \mathrm{~g} / \mathrm{L} \mathrm{NaCl}$ and different initial $\mathrm{pH}$ values. In all experiments, the electrolysis was performed at a potential of $6 \mathrm{~V}$, and the solution was monitored as a function of the time. The curves of percent COD removal as a function of electrolysis time at different $\mathrm{pH}$ values are shown in Figure 9. At $\mathrm{pH} 4$ and 9, the percent COD removal increases approximately linearly with electrolysis time. For these $\mathrm{pH}$ values, the amounts of COD removed at a given electrolysis time are similar, with the value obtained under acidic conditions being slightly greater than that under basic conditions. At $\mathrm{pH} \mathrm{7,} \mathrm{the} \mathrm{percent} \mathrm{COD}$ removal remains at approximately $79 \%$ for electrolysis times up to $45 \mathrm{~min}$, and then increases with further electrolysis. The percent COD removal during the initial 45 min is thus much lower at $\mathrm{pH} 7$ than at $\mathrm{pH} 4$ and 9. For all three $\mathrm{pH}$ values, the percent COD removal converges to close to $100 \%$ after $120 \mathrm{~min}$ of electrolysis. These findings indicate that COD removal is favored at $\mathrm{pH} 4$ and 9 compared to $\mathrm{pH} 7$, but that almost $100 \%$ removal is obtained for all systems after $120 \mathrm{~min}$ of electrolysis.

Figure 10 shows the percent color removal as a function of electrolysis time for wastewater samples contain-

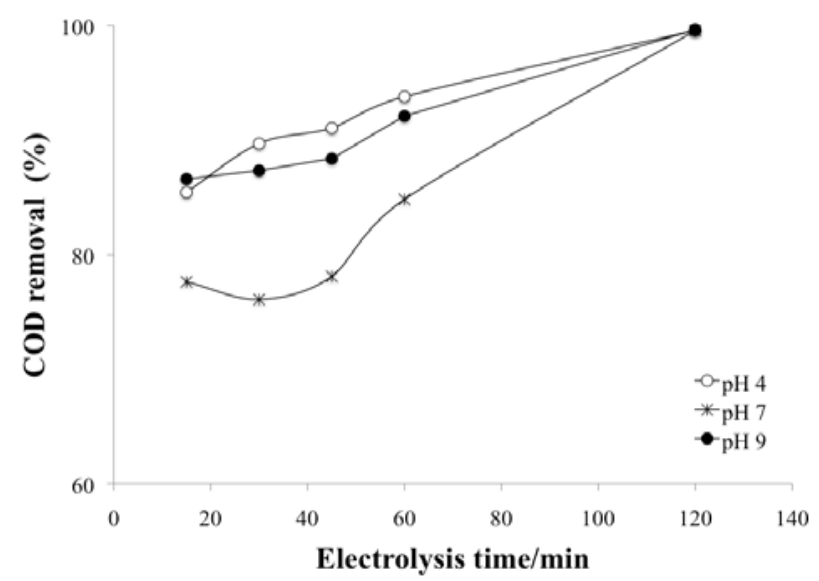

Figure 9. Percent COD removal as a function of electrolysis time at different $\mathrm{pH}$ values. Chloride concentration, $5 \mathrm{~g} / \mathrm{L}$. Cell potential difference, $6 \mathrm{~V}$.

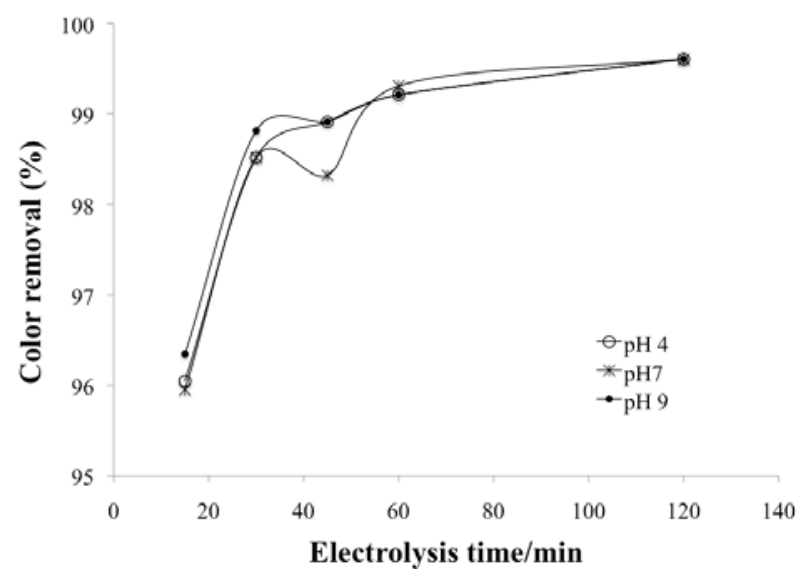

Figure 10. Percent color removal as a function of the electrolysis time for wastewater samples with different $\mathrm{pH}$ values. Chloride concentration, $5 \mathrm{~g} / \mathrm{L}$; cell potential difference, $6 \mathrm{~V}$.

ing $5 \mathrm{~g} / \mathrm{L} \mathrm{NaCl}$ with different $\mathrm{pH}$ values. The percent color removal reaches $96 \%$ by $15 \mathrm{~min}$ of electrolysis and then continues to increase, reaching $100 \%$ after $120 \mathrm{~min}$. Similar behavior was observed at each of the three $\mathrm{pH}$ values tested ( $\mathrm{pH} \mathrm{4,} 7$ and 9), indicating that the elimination of the organic matter responsible for the color of the paper mill wastewater does not significantly affect the $\mathrm{pH}$ of the sample.

Figure 11 shows the percent polyphenol removal as a function of electrolysis time in wastewater samples containing $5 \mathrm{~g} / \mathrm{L} \mathrm{NaCl}$ with different $\mathrm{pH}$ values. At all of the $\mathrm{pH}$ values studied, the percent polyphenol removal reaches a very high value within a relatively short electrolysis time (15 min), and then continues to increase with further electrolysis.

At each of the $\mathrm{pH}$ values tested, the percent polyphenol removal increases from approximately $95 \%$ to $99 \%$ as the electrolysis time increases from 15 to $120 \mathrm{~min}$.

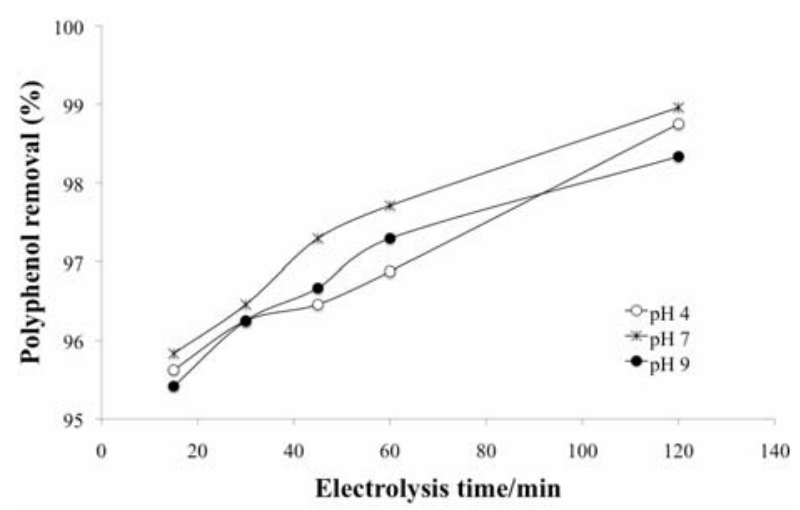

Figure 11. Percent polyphenol removal as a function of electrolysis time for wastewater samples with different $\mathbf{p H}$ values. Chloride concentration, $5 \mathrm{~g} / \mathrm{L}$; cell potential difference, $6 \mathrm{~V}$. 
Thus, the removal of polyphenols from paper mill wastewater is almost independent of the $\mathrm{pH}$ of the electrolyte solution.

The results presented above demonstrate that varying the $\mathrm{pH}$ in the range of 4 to 9 has little effect on the removal of COD, color, and polyphenols during electrochemical oxidation of paper mill wastewater containing $5 \mathrm{~g} / \mathrm{L} \mathrm{NaCl}$.

Similar results were obtained by Gotsi et al. [29], Rajkumar and Palanivelu [25], Israilides et al. [30] and Umran Tezcan Un et al. [31]. In this regard, Rajkumar and Palanivelu [25] emphasized that initial $\mathrm{pH}$ does not significantly affect the degradation of organic pollutants in the range of 3.0-10.0 using a Ti/ $\mathrm{TiO}_{2}-\mathrm{RuO}_{2}-\mathrm{IrO}_{2}$ anode. The $\mathrm{Ti} / \mathrm{RuPb}(40 \%) \mathrm{Ox}$ anode used in the present experiments showed similar behavior.

The values of the paper mill wastewater parameters before and after electrochemical oxidation treatment are listed in Table 2. Electrochemical oxidation using the $\mathrm{Ti} / \mathrm{RuPb}(40 \%) \mathrm{Ox}$ anode under optimal operating conditions showed good purification performance, affording satisfactory reductions in COD, color, turbidity, and polyphenol content. The process does, however, increase the chloride content and electrical conductivity of the wastewater due to the addition of $\mathrm{NaCl}$.

The advantage of electrochemical oxidation method over other methods used in the treatment of effluents from paper industry is the ability to oxidize recalcitrant organic compounds that resist biological methods $(6,7)$ or combined system of activated sludge and ozonation (9). Comparable values of COD, color and polyphenol removal from electrochemical oxidation have been obtained with combined treatment as coagulation-flocculation followed by heterogeneous photocatalysis (8) or electrocoagulation $(12,14-16)$, however, the sludge production by electrochemical oxidation is negligible.

Table 2. Comparatives parameters of the raw paper mill wastewater before and after electrochemical treatment.

\begin{tabular}{|c|c|c|}
\hline \multirow[b]{2}{*}{ Parameters } & \multicolumn{2}{|c|}{ Paper mill wastewater } \\
\hline & Raw & $\begin{array}{c}\text { After } \\
\text { Electrchemcal } \\
\text { treatment* }\end{array}$ \\
\hline $\mathrm{pH}$ & 6.3 & 7.9 \\
\hline $\operatorname{COD}\left(\mathrm{mg} \mathrm{L}^{-1}\right)$ & 2585 & 3 \\
\hline Color $\left(\mathrm{m}^{-1}\right)$ & 101.2 & 0.1 \\
\hline Turbidity (NTU) & 486 & n.d \\
\hline $\operatorname{TDS}\left(\mathrm{mg} \mathrm{L}^{-1}\right)$ & 2.1 & 4.9 \\
\hline Chloride concentration $\left(\mathrm{mg} \mathrm{L}^{-1}\right)$ & 80 & 180 \\
\hline Total polyphenols $\left(\mathrm{mg} \mathrm{L}^{-1}\right)$ & 48 & 0.8 \\
\hline Conductivity $\left(\mathrm{mS} \mathrm{cm}^{-1}\right)$ & 2.9 & 8.4 \\
\hline
\end{tabular}

* Electrochemical oxidation of a wastewater sample containing $5 \mathrm{~g} / \mathrm{L} \mathrm{NaCl}$; $\mathrm{pH}$ 6.3; cell potential difference, $6 \mathrm{~V}$; electrolysis time, $120 \mathrm{~min}$.
Important factors in the electrochemical oxidation process are the properties of anode material and the presence of $\mathrm{NaCl}$ as electrolyte, which facilitates the process via an indirect mechanism with the participation of hypochlorite ions. In this study the $\mathrm{Ti} / \mathrm{RuPb}(40 \%) \mathrm{Ox}$ anode has showed a suitable performance.

\section{Conclusions}

The present study demonstrates that the electrochemical oxidation of paper mill wastewater using a dimensionally stable anode with composition $\mathrm{Ti} / \mathrm{RuPb}(40 \%) \mathrm{Ox}$ significantly lowers the organic content, color, and polyphenol content. Addition of $5 \mathrm{~g} / \mathrm{L} \mathrm{NaCl}$ to the wastewater prior to treatment enhanced the purification process, allowing a given degree of purification to be achieved at a smaller potential difference and shorter electrolysis time. Varying the $\mathrm{pH}$ within the range of 4 to 9 did not have a marked effect on the removal of COD, color, and polyphenols. The emergence of an absorption band in the UV-Vis spectrum at $292 \mathrm{~nm}$ during electrolysis suggested that the anodic oxidation occurs via an indirect mechanism with the participation of the hypochlorite ion responsible for the oxidation of organic matter.

\section{Acknowledgement}

The authors thank VIEP of the Benemérita Universidad Autónoma de Puebla for financial support.

\section{References}

[1] M. Ali and T. R. Sreekrishnan, "Aquatic Toxicity from Pulp and Paper Mill Effluents: A Review," Advances in Environmental Research, Vol. 5, No. 2, 2001, pp. 175196. doi:10.1016/S1093-0191(00)00055-1

[2] E. R. Nestmann, "Detection of Genetic Activity in Effluent from Pulp and Paper Mills: Mutagenicity in Saccharomyces Cerevisiae," In: F. K. Zimmerman, R. E. Taylor-Mayer, Eds., Testing in Environmental Pollution Control, Horwood, London, 1985, pp. 105-117.

[3] G. Thompson, J. Swain, M. Kay and C. F. Forster, "The Treatment of Pulp and Paper Mill Effluent: A Review," Bioresource Technology, Vol. 77, No. 3, 2001, pp. 275286. doi:10.1016/S0960-8524(00)00060-2

[4] D. Pokhrel and T. Viraraghavan, "Treatment of Pulp and Paper Mill Wastewater," Science of the Total Environment, Vol. 333, No. 1-3, 2004, pp. 37-58. doi:10.1016/j.scitotenv.2004.05.017

[5] M. Belmont, C. Xavier, J. Decap, M. Martinez, P. Sierra-Alvarez and G. Vidal, "Improved Aerobic Biodegradation of a Abietic Acid in ECF Bleached Kraft Mill Effluent due to Biomass Adaptation," Journal of Hazardous. Material, Vol. 135, No. 1-3, 2006, pp. 256-263. 
doi:10.1016/j.jhazmat.2005.11.061

[6] P. Malavyva and V. S. Rathore, "Biorremediation of Pulp and Paper Mill Effluent by A Novel Fungal Consortium Isolated From Polluted Soil," Bioresource Technology, Vol. 98, No. 18, 2007, pp. 3647-3651. doi:10.1016/j.biortech.2006.11.021

[7] I. C. Nair, K. Jayachandran and S. Shashidhar, "Treatment of Paper Factory Effluent using a Phenol Degrading Alcaligenes sp under Free and Immobilized Condition," Bioresource Technology, Vol. 98, No. 3, 2007, pp. 714716. doi:10.1016/j.biortech.2006.02.034

[8] A. C. Rodrigues, M. Boroski, N. S. Shimada, J. C. Garcia, J. Nozaki and N. Hioka, "Treatment of Paper Pulp and Paper Mill by Coagulation-Flocculation followed by Heterogeneous Photocatalysis," Journal of Photochemistry and Photobiology A, Vol. 194, No. 1, 2008, pp. 1-10.

doi:10.1016/i.jphotochem.2007.07.007

[9] M. R. Assalin, E. S. Almeida and N. Durán, "Combined System of Activated Sludge and Ozonation for the Treatment of Kraft $\mathrm{E}_{1}$ Effluent," International Journal of Environmental Research and Public Health, Vol. 6, No. 3, 2009, pp. 1145-1154. doi:10.3390/ijerph6031145

[10] M. R. Assalin, M. A. Rosa and N. Durán, "Remediation of Kraft Effluent by Ozonation: Effect of Applied Ozone Concentration and Initial pH," Ozone: Science \& Engineering, Vol. 26, No. 3, 2004, pp. 317-322. doi:10.1080/01919510490456196

[11] M. R. Assalin, E. S. Almeida, M. A. Rosa, S. G. Moraes and N. Durán, "Application of Ozonization Process in Industrial Wastewaters: Textile, Kraft E1 and Whey Effluents," Environmental Technology, Vol. 25, No. 8, 2004, pp. 867-872. doi:10.1080/09593330.2004.9619379

[12] S. Mahesh, B. Prasad, I. D. Mall and I. M. Mishra, "Electrochemical Degradation of Pulp and Paper Mill Wastewater. Part 1. COD and Color Removal," Industrial \& Engineering Chemistry Research, Vol. 45, No. 48, 2006, pp. 2830-2839. doi:10.1021/ie0514096

[13] G. Chen, "Electrochemical Technologies in Wastewater Treatment," Separation and Purification Technology, Vol. 38, No. 1, 2004, pp. 11- 41. doi:10.1016/j.seppur.2003.10.006

[14] A. P. Buzzini, A. J. Motheo and E. C. Pires, "Assessment of Electrochemical and Chemical Coagulation as Posttreatment for the Effluents of a UASB Reactor Treating Cellulose Pulp Mill Wastewater," Water Science and Technology, Vol. 52, No. 1-2, 2005, pp. 183-188.

[15] M. Uğurlu, M. H. Karaoğlu and İ. Kula. "Experimental Investigation of Chemical Oxygen Demand, Lignin and Phenol Removal from Paper Mill Effluents Using ThreePhase Three-Dimensional Electrode Reactor," Polish Journal of Environmental Studies, Vol. 15, No. 4, 2006, pp. 647-654.

[16] M. Zaied and N. Bellakhal, "Electrocoagulation Treatment of Black Liquor from Paper Industry," Journal of Hazardous Material, Vol. 163, No. 2-3, 2009, pp. 9951000. doi:10.1016/j.jhazmat.2008.07.115

[17] S. Khansorthong and M. Hunsom, "Remediation of Wa- stewater from Pulp and Paper Mill Industry by the Electrochemical Technique," Chemical Engineering Journal, Vol. 151, No. 1-3, 2009, pp. 228-234. doi:10.1016/j.cej.2009.02.038

[18] H. B. Beer, "The Invention and Industrial Development of Metal Anodes," Journal of the Electrochemical Society, Vol. 127, No. 8, 1980, pp. 303C-307C. doi:10.1149/1.2130021

[19] S. Trasatti, "Electrocatalysis: Understanding the Success of DSA ${ }^{\circledR}, "$ Electrochimica Acta, Vol. 45, No. 15-16, 2000, pp. 2377-2385. doi:10.1016/S0013-4686(00)00338-8

[20] C. Comninellis and G. P. Vercesi, "Characterization of DSA Type Oxygen Evolving Electrodes: Choice of a Coating," Journal of Applied Electrochemistry, Vol. 21, No. 4, 1991, pp. 335-345. doi:10.1007/BF01020219

[21] APHA (American Public Health Association), "Standard Methods for the Examination of Water and Wastewater," 20th Edition, APHA, American Water Works Association, and Water Pollution Control Federation, Washington, D.C., 1998.

[22] T. Zayas, V. Rómero, L. Salgado, M. Meraz and U. Morales, "Applicability of Coagulation/Flocculation and Electrochemical Processes to the Purification of Biologically Treated Vinasse Effluent," Separation and Purification Technology, Vol. 57, No. 2, 2007, pp. 270-276. doi:10.1016/j.seppur.2007.04.019

[23] K. Rajeshwar, J. G. Ibañez and G. M. Swain, "Electrochemistry and Environment," Journal of Applied Electrochemistry, Vol. 24, No. 11, 1994, pp. 1077-1091. doi:10.1007/BF00241305

[24] U. B. Öğütv Eren, E. Torüe and S. Koparal, "Removal of Cyanide by Anodic Oxidation for Wastewater Treatment," Water Research, Vol. 33, No. 8, 1999, pp. 18511856. doi:10.1016/S0043-1354(98)00362-5

[25] D. Rajkumar and K. Palanivelu. "Electrochemical Treatment of Industrial Wastewater," Journal of Hazardous Materials, Vol. 113, No. 1-3, 2004, pp. 123-129. doi:10.1016/j.jhazmat.2004.05.039

[26] Y. Feng, D. W. Smith and J. R. Bolton, "Photolysis of Aqueous Free Chlorine Species ( $\mathrm{HOCl}$ and $\mathrm{OCl}^{-}$) with $254 \mathrm{~nm}$ Ultraviolet Light," Journal of Environmental Engineering and Science, Vol. 6, No. 3, 2007, pp. 277284. doi:10.1139/S06-052

[27] D. Rajkumar, B. J. Song and J. G. Kim, "Electrochemical Degradation of Reactive Blue 19 in Chloride Medium for the Treatment of Textile Dyeing Wastewater with Identification of Intermediate Compounds," Dyes and Pigments, Vol. 72, No. 1, 2007, pp. 1-7. doi:10.1016/j.dyepig.2005.07.015

[28] C. R. Costa and P. Olivi, "Effect of Chloride Concentration on the Electrochemical Tretment of Synthetic Tannery Wastewater," Electrochimimica Acta, Vol. 54, No. 7, 2009, pp. 2046-2052. doi:10.1016/j.electacta.2008.08.033

[29] M. Gotsi, N. Kalogerakis, E. Psillakis, P. Samaras and D. Mantzavinos, "Electrochemical Oxidation of Olive Oil Mill Wastewaters," Water Research, Vol. 39, No. 17, 2005, pp. 4177-4187. doi:10.1016/j.watres.2005.07.037 
[30] C. J. Israilides, A. G. Vlyssides, V. N. Mourafeti and G. Karvouni, "Olive Oil Wastewater Treatment with the Use of an Electrolysis System," Bioresource Technolology, Vol. 61, No. 2, 1997, pp. 163-170.

doi:10.1016/S0960-8524(97)00023-0
[31] U. Tezcan Un, U. Altay, A. S. Koparal and U. B. Ogutveren, "Complete Treatment of Olive Mill Wastewaters by Electrooxidation," Chemical Engineering Journal, Vol. 139, No. 3, 2008, pp. 445-452.

doi:10.1016/j.cej.2007.08.009 